University of Nebraska - Lincoln

DigitalCommons@University of Nebraska - Lincoln

Faculty Publications in Food Science and Technology

Food Science and Technology Department

8-2005

\title{
Grain Quality of Brazilian Maize Genotypes as Influenced by Nitrogen Level
}

\author{
Aildson P. Duarte \\ Stephen C. Mason \\ University of Nebraska-Lincoln, smason1@unl.edu \\ David S. Jackson \\ University of Nebraska-Lincoln, djackson1@unl.edu \\ Jorge de C. Kiehl \\ University of Nebraska-Lincoln
}

Follow this and additional works at: https://digitalcommons.unl.edu/foodsciefacpub

Part of the Food Science Commons

Duarte, Aildson P.; Mason, Stephen C.; Jackson, David S.; and Kiehl, Jorge de C., "Grain Quality of Brazilian Maize Genotypes as Influenced by Nitrogen Level" (2005). Faculty Publications in Food Science and Technology. 114.

https://digitalcommons.unl.edu/foodsciefacpub/114

This Article is brought to you for free and open access by the Food Science and Technology Department at DigitalCommons@University of Nebraska - Lincoln. It has been accepted for inclusion in Faculty Publications in Food Science and Technology by an authorized administrator of DigitalCommons@University of Nebraska - Lincoln. 


\title{
Grain Quality of Brazilian Maize Genotypes as Influenced by Nitrogen Level
}

\author{
Aildson P. Duarte, Stephen C. Mason,* David S. Jackson, and Jorge de C. Kiehl
}

\begin{abstract}
Maize (Zea mays L.) is an important crop in Brazil, and concerns about grain quality are increasingly important with increasing exports and use of grain for specific end-uses. A wide range of genotypes are grown and $\mathbf{N}$ application is required to produce high yields. The objectives of these studies were to: (i) determine $\mathrm{N}$ application effects on the kernel hardness and breakage susceptibility of a wide range of Brazilian genotypes ranging from dent to flint kernel types and (ii) determine relationships among kernel hardness and breakage susceptibility tests, yield and $\mathbf{N}$ and oil concentration. Three studies were conducted with a broad range of maize genotypes and $\mathrm{N}$ application rates of $0,60,120$, and $180 \mathrm{~kg} \mathrm{ha}^{-1}$. Grain was harvested and yields corrected for water content, and grain was evaluated through a series of chemical and physical quality tests. Application of $180 \mathbf{~ k g}$ $\mathrm{ha}^{-1} \mathrm{~N}$ application increased grain yield by 747 to $1466 \mathrm{~kg} \mathrm{ha}^{-1}$, increased grain $\mathrm{N}$ concentration by 0.9 to $2.4 \mathrm{~g} \mathrm{~kg}^{-1}$, and increased hardness to a lesser extent, while reducing breakage susceptibility by 1.9 to $6.9 \%$. Genotype had a much larger influence on grain quality parameters than did $\mathbf{N}$ rate. The limited correlation between grain yield, grain $\mathbf{N}$ concentration, and grain oil concentration to kernel hardness suggests that development of further improved genotypes with high maize yields and excellent dry milling grain quality is feasible in Brazil. The large variation in grain yield and dry milling grain quality in intermediate kernel-type (semident, semiflint) genotypes used in Brazil presents short-term potential to select hybrids that produce both high yield and good dry milling grain quality.
\end{abstract}

$\mathrm{M}$ AIZE is one of the most important grain crops produced in Brazil, with over 12 million hectares in production (FAO, 2003). Brazilian maize genotypes have great genetic diversity, consisting of varieties, and single-cross, double-cross, and three-way hybrids. Genotype germplasm sources range from temperate to tropical and from dent to flint kernel characteristics.

In recent years, Brazilian producers have become concerned about maize grain quality, particularly hardness. Flint and intermediate (semident and semiflint) genotypes are preferred since it is assumed that grain produced by dent genotypes breaks more easily during handling (Corrêa et al., 2004). Kernel hardness classification in Brazil is largely based on visual appearance, and objective evaluation of kernel hardness and breakage susceptibility using grain quality tests has not been done to date. Previous studies in the USA indicate that the relationship between kernel hardness and breakage susceptibility among genotypes and across production prac-

Contribution of the Dep. of Agronomy \& Horticulture and Dep. of Food Science \& Technology, Nebraska Agric. Res. Div., Univ. of Nebraska, Lincoln, NE 68583 (Journal Series No. 14759; and Campinas Institut Agronomic, 19800-000 Assis, Brazil.) Received 5 Oct. 2004.*Corresponding author (smason1@unl.edu).

Published in Crop Sci. 45:1958-1964 (2005).

Crop Ecology, Management \& Quality

doi:10.2135/cropsci2004.0587

(c) Crop Science Society of America

677 S. Segoe Rd., Madison, WI 53711 USA tices is weak (Dorsey-Redding et al., 1991; Kniep and Mason, 1989). Nitrogen effects on maize grain quality in Brazil have not been documented.

Grain quality assessments have traditionally been largely based on kernel soundness, broken kernels, and absence of extraneous material and mycotoxins, which are important to all end-uses. In addition, processors and breeding programs rely on numerous empirical tests to identify desirable physical and chemical kernel traits that subjectively predict processing characteristics (Shandera et al., 1997). Test weight, a measure of bulk density, is a rapid method widely used in grain handling and processing. The Stenvert micro-hammermill and Tangential Abrasive Dehulling Device (TADD) are laboratory tests used for determination of kernel hardness (Pomeranz et al., 1985; Reichert et al., 1986). The Wisconsin breakage tester determines kernel breakage susceptibility by impacting kernels against a steel surface with centrifugal force (Singh and Finner, 1983; Watson and Hercum, 1986). The amount of low density kernels often is measured as the percentage of kernels floating in a sodium nitrate solution (Peplinski et al., 1989).

Wet millers and dry-grind fuel processors prefer slightly softer grain with lower protein content and high test weights (Fox et al., 1992). In contrast, dry millers and alkaline-cooked processors prefer harder grain that results in higher flaking grit yield and more predictable cooking times (Shandera et al., 1997). Dry milling performance is predicted well by low TADD removal, high Stenvert hardness weight, and low percentage of floaters (Shandera et al., 1997; Wehling et al., 1996).

Nitrogen fertilizer application is required to optimize maize grain yields and tends to improve physical grain quality in maize by increasing kernel weight (Bauer and Carter, 1986; Kniep and Mason, 1989), kernel density (Kniep and Mason, 1989; Paulsen et al., 1983), and protein and zein concentration (Manoharkumar et al., 1978; Oikeh et al., 1998; Arnold et al., 1977), while decreasing kernel breakage susceptibility (Kniep and Mason, 1989; Johnson and Russell, 1982). Increasing $\mathrm{N}$ supply to maize plants increases zein concentrations in the endosperm, creating harder and more translucent grains (Tsai et al., 1984, 1992).

With increasing maize production, export marketing and domestic specific end-use of maize grain in Brazil, research to document the influence of genotypes and production practices such as $\mathrm{N}$ application on maize grain quality is needed but not presently available. The objectives of these studies were to: (i) determine $\mathrm{N}$ application effects on grain yield, kernel hardness and breakage susceptibility of a wide range of Brazilian genotypes and (ii) determine relationships among kernel hardness and breakage susceptibility tests, yield, and $\mathrm{N}$ and oil concentration of grain for diverse genotypes and production conditions in Brazil. 


\section{MATERIALS AND METHODS}

\section{Field Experiments}

Experiments were conducted in Sao Paulo State, Brazil, in the 2000-2001 and 2001-2002 growing seasons. Three experiments included 5 to 10 genotypes and four $\mathrm{N}$ application rates. Experimental locations included a sandy loam textured Eutrudox soil at Votuporanga (S 20 25' W 5004; $500 \mathrm{~m}$ elevation) in 2000-2001, and a clay textured Hapludox soil at Palmi-

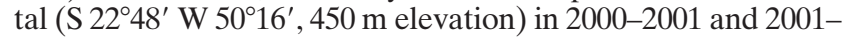
2002. All experiments were conducted with a randomized complete block design with four replications.

The genotypes used varied among the experimental sites and represent the range of maize diversity produced in Brazil (Table 1). Genotypes were selected by visual characterization for hardness on the basis of kernel appearance and degree of denting. The chosen genotypes differed by germplasm source, cross type, maturity classification $\left({ }^{\circ} \mathrm{C}\right.$ days with $8^{\circ} \mathrm{C}$ base temperature from emergence with very early $<1450$, early $=1450$ to 1600 , intermediate $=1600$ to 1700 , and late $>1700$ ), and kernel appearance and color [Hunter Color Lab Color System using a Minolta Chroma Meter CR-300 (Minolta Corp., Ramsy, NJ)]. Nitrogen rates were zero, 60, 120, and $180 \mathrm{~kg} \mathrm{ha}^{-1}$ side dress applied as equal applications of urea or ammonium nitrate at the 4 to 6-leaf stage (approximately $30 \mathrm{DAP}$ ) and at the 8- to 10-leaf stage (approximately 45 DAP).

Experimental plots were four $90-\mathrm{cm}$ rows wide $(3.6 \mathrm{~m})$ and 6 to $10 \mathrm{~m}$ long with previous autumn-winter crops of maize at Palmital and wheat (Triticum aestivum L.) at Votuporanga. Plots were no-till planted at Palmital 2000-2001 on 25 October and harvested on 28 February, planted at Palmital 2001-2002 on 15 November and harvested on 10 March, and at Votuporanga planted on 22 November and harvested on 23 March. Average monthly temperatures were between 25 and $26^{\circ} \mathrm{C}$ for all production environments. Precipitation was $794 \mathrm{~mm}$ at Palmital 2000-2001 and 771 at Palmital 2001-2002 with over half occurring during the months of January and February. Precipitation at Votuporanga was $626 \mathrm{~mm}$ with 117 to $145 \mathrm{~mm}$ per month in December, January, and February, and $192 \mathrm{~mm}$ in March.

All plots were overseeded at twice the desired plant population, and thinned at the 3-leaf stage to 55500 to 57500 plants $\mathrm{ha}^{-1}$. Weed control was done by use of herbicide application and manual weeding. Puccinia polysora Underw. and Phaeosphaeria maydis (P. Henn.) Rane, Payak \& Renfro were present at Palmital 2001-2002 and since some genotypes were susceptible plots were sprayed with a fungicide at 30,45 , and 60 DAP. Plots were hand-harvested and mechanically shelled when the latest maturing genotype reached $270 \mathrm{~g} \mathrm{~kg}^{-1}$ water content, except at Palmital in 2001-2002 when plots were harvested at physiological maturity, dried and hand shelled. This was done due to this experiment also being used for determination of dry matter production and nutrient uptake, and partitioning among plant parts (Duarte et al., 2003). The major effect of the harvesting-shelling method would be that hand shelling reduces stress cracks and breakage susceptibility. The middle 3.0 to $3.5 \mathrm{~m}$ of the two center rows were harvested for all plots and grain yields were corrected to $145 \mathrm{~g} \mathrm{~kg}^{-1}$ water concentration.

\section{Grain Quality Analysis}

Grain N concentrations were determined at the Sao Paulo University, Piracicaba, Brazil, by a micro-khjeldahl method for N (AOAC, 1990a). Oil concentrations were determined at the Agronomic Institute, Campinas, Brazil, by the ether extract method for oil (AOAC, 1990b). Samples from the Votuporanga and Palmital 2000-2001 experiments were stored in a freezer at $-4^{\circ} \mathrm{C}$ after harvest, while the grain from the Palmital 2001-2002 were stored in a refrigerator at $6^{\circ} \mathrm{C}$. In May 2002, the grain samples were shipped to the University of Nebraska and frozen at $-4^{\circ} \mathrm{C}$ until physical grain quality parameters were measured.

All grain samples were removed from the freezer at 100 to $120 \mathrm{~g} \mathrm{~kg}^{-1}$ water content, equilibrated to ambient conditions and cleaned by sieving on 5-mm screens before quality measurement. Kernel weights were determined by counting and weighing two 100-kernel subsamples. Kernel test weights were taken with a Dickey-John grain tester (Model GAC II, Dickey John Corp., Auburn, IL). Kernel breakage susceptibility was measured by the Wisconsin Breakage Susceptibility test (Model 9/84, Cargill Grain Research Laboratory, Minneapolis, MN) on the basis of procedures of Paulsen and Hill (1985) using 110-g grain samples. Percentage of breakage was calculated from the weight remaining on 5.6-mm sieves after shaking for $90 \mathrm{~s}$. Apparent corn density was determined by the floaters test, the percentage of buoyant kernels immersed in an aqueous sodium nitrate solution with a specific gravity of $1.275 \mathrm{~g} / \mathrm{cm}^{3}$. Specific density and porosity were determined with an air comparison pycnometer (Model 930, Beckman Instruments, Inc., Fullerton, CA) (Wu and Bergquist, 1991; Thompson and Isaacs, 1967). Kernel hardness was determined with the TADD (Model 4E-220, Venables Machine Works, Saskatoon, SK, Canada) and TADD loss was the percent loss of kernel material after abrading $20 \mathrm{~g}$ of maize grain for $10 \mathrm{~min}$ while suctioning off abraded material (Reichart et al., 1986). In addition the Stenvert Hardness test (Micro Hammer Mill V, Glen Mills Inc., Maywood, NJ) was used with $20 \mathrm{~g}$ of maize grain being ground with a micro-hammer mill with a $2-\mathrm{mm}$ screen at 360 rpm. Heights of "soft" endosperm and total ground material

Table 1. Characterization of maize cultivars used in studies at Palmital and Votuporanga, Brazil.

\begin{tabular}{|c|c|c|c|c|c|c|c|}
\hline Genotype & Company & $\begin{array}{c}\text { Primary } \\
\text { germplasm }\end{array}$ & Hybrid type & $\begin{array}{c}\text { Maturity } \\
\text { classification }\end{array}$ & $\begin{array}{c}\text { Kernel } \\
\text { appearance }\end{array}$ & Kernel color & Location/years \\
\hline P32R21 & Pioneer & temperate & single cross & very early & dent & yellow & Palmital 2001-2002 \\
\hline DKB212 & Dekalb & & & & & low opac & Palmital 2001-2002 \\
\hline BR3123 & Embrapa & tropical & three-way cross & intermediate & intermediate & yellow rec & $\begin{array}{l}\text { Votuporanga 2000-2001, Palmital 2000-2001 } \\
\text { and 2001-2002 }\end{array}$ \\
\hline BRS4157 & Embrapa & tropical & variety & early & flint & orange opaque & $\begin{array}{l}\text { Votuporanga 2000-2001, Palmital 2000-2001 } \\
\text { and 2001-2002 }\end{array}$ \\
\hline 766 & Dow & intermediate & three-way cross & intermediate & intermediate & & Votuporanga 2000-2001, Palmital 2000-2001 \\
\hline & Dow & intermediate & single cross & intermediate & intermediate & yellow bright & Votuporanga 2000-2001, Palmital 2000-2001 \\
\hline 9560 & Dow & tropical & single cross & intermediate & intermediate & yellow & Votuporanga 2000-2001, Palmital 2000-2001 \\
\hline Master & Syngenta & intermediate & three-way cross & intermediate & intermediate & yellow & Votuporanga 2000-2001, Palmital 2000-2001 \\
\hline Tork & Syngenta & intermediate & single cross & intermediate & intermediate & yellow & Votuporanga 2000-2001, Palmital 2000-2001 \\
\hline DKB251 & Dekalb & intermediate & three-way cross & intermediate & intermediate & yellow & Votuporanga 2000-2001, Palmital 2000-2001 \\
\hline AG1051 & Agroceres & tropical & double cross & late & dent & orange opaque & Palmital 2000-2001 and 2001-2002 \\
\hline DK333B & Dekalb & tropical & single cross & late & intermediate & yellow & Palmital 2000-2001 \\
\hline
\end{tabular}


collected in the recovery tube, time to grind, reduced hammer mill rpm at maximum grinding power, and quantity of hard endosperm recovered over a $425-\mu \mathrm{m}$ sieve were measured (Pomeranz et al., 1985). Hard kernels had low TADD loss and Stenvert soft endosperm height, and high Stenvert time to grind, reduction in hammer mill rpm and quantity of hard endosperm recovered.

\section{Statistical Analysis}

All grain physical quality tests were performed in duplicate, and the mean value was analyzed statistically. Analysis of variance was conducted for grain yield and quality parameters by Mixed Models of the SAS package as presented by Littel et al. (1996) for each study separately because of use of different genotypes, except for Votuporanga and Palmital in 2000-2001, where the same genotypes were present. Orthogonal contrasts were used for mean separation as shown in Tables 2, 3, and 4. Data from the three experiments were pooled to provide the range of maize germplasm grown in Brazil, and a broad range of environmental conditions and different harvest methods for calculation of Pearson correlations among grain quality parameters and grain yield.

\section{RESULTS AND DISCUSSION Genotype Differences}

Genotype differences for grain yield, $\mathrm{N}$ and oil concentrations, and physical quality parameters were present for all trials (Tables 2 and 3), while few genotype by $\mathrm{N}$ rate interactions were found. Average grain yields ranged from 6.3 to $7.4 \mathrm{Mg} \mathrm{ha}^{-1}$, similar to average Brazilian grain yields (IBGE, 2003). Test weights and true densities were greater than reported for the temperate North American climates (Vyn and Tollenaar, 1998; Yuan and Flores, 1996), except for the Palmital 20012002 location (Table 3). Great variability among genotypes for both grain yield and quality were present (Tables 2 and 3 ).

Across the three studies, dent genotypes consistently had a higher percentage of floaters, Stenvert height of soft endosperm, and TADD removal than intermediate which were greater than dent grain genotypes, while flint genotypes were greater than intermediate which were greater than dent for grain $\mathrm{N}$ concentration, test weight, density, and Stenvert reduced rpm at maximum grinding power (Tables 2 and 3). This indicated that flint genotypes produced the hardest kernels and dent genotypes the softest kernels. In contrast, grain yields of intermediate kernel-type genotypes produced higher grain yields than the flint and dent genotypes at both locations in 2000-2001 (Table 2), while at Palmital 20012002 , the yield was only $0.5 \mathrm{Mg} \mathrm{ha}^{-1}$ lower (Table 3). At Palmital and Votuporanga in 2000-2001, where six intermediate kernel-type (semiflint and semident kernels) genotypes were included, large variation existed among these genotypes for grain yield, grain $\mathrm{N}$ concentration, test weight, TADD removed, and breakage susceptibility (Table 2). Within intermediate genotypes, those with more flint appearance $(8410,9560$, and DK 251) had lower grain yield, TADD removal, and breakage susceptibility but higher test weight than the more dent appearing genotypes (BR 3123, Master, and Tork).
At Palmital 2001-2002, where three dent genotypes were included, tropical dent genotypes produced higher grain yields and harder kernels as indicated by Stenvert reduced rpm at maximum grinding power and amount of hard endosperm, TADD removal, and breakage susceptibility than the temperate genotype (Table 3 ). They also had lower grain $\mathrm{N}$ concentration and Stenvert time to grind. Differences between the two dent genotypes with temperate germplasm were found for yield, $\mathrm{N}$ concentration, and nearly half of the other grain quality parameters measured. These data indicate considerable grain quality variation and that with proper grain quality characterization and genotype evaluation, it should be possible to identify high yielding intermediate kernel type genotypes with the hard kernels desirable for dry milling in Brazil (Shandera et al., 1997; Wehling et al., 1996).

Large variations for grain quality exist among maize genotypes commonly grown in Brazil. In this study, visual assessment of grain was used to select the genotypes used on the basis of kernel appearance and degree of denting, which provided a general characterization of the physical quality of grain but did not account for genotypic differences within kernel type nor other subtle, but important, differences in grain quality. On the basis of maize genotype, production environments (location and year) and method of harvesting, large variations in grain quality occurred (Tables 2 and 3 ) that were not detectable by the visual assessment used to select the hybrids to include in this study.

\section{Nitrogen Rate}

In all locations, increasing $\mathrm{N}$ rate increased grain yield and $\mathrm{N}$ concentration of maize grain (Tables 4 and 5), as previously reported (Mason and D'Croz-Mason, 2002). The grain yield response of maize was modest for these tropical soils but was due to a history of no-till and fertilizer application for high yields of maize and wheat for five or more years before this study. At Palmital in 2000-2001, increasing $\mathrm{N}$ rate had a greater effect on hardness as measured by floaters, Stenvert reduced rpm at maximum grinding power, time to grind, weight and height of hard endosperm, and TADD removed than at Votuporanga 2000-2001, but a similar effect on test weight and breakage susceptibility was found at both locations (Table 4). At Palmital in 2001-2002, increasing $\mathrm{N}$ rate resulted in increasing $\mathrm{N}$ concentration, and decreasing TADD removal and breakage susceptibility, but had little effect on other quality parameters (Table 5). Even though a wide range of genotypes were used in these studies, genotype $\times \mathrm{N}$ rate interactions were only found for Stenvert height of soft and hard endosperm and weight of hard endosperm at the Votuporanga 2000-2001 and Palmatal 2000-2001 locations. These results support studies in temperate U.S. climates (Bauer and Carter, 1986; Kniep and Mason, 1989) that N application tends to increase kernel hardness and decrease breakage susceptibility, but the differences were small and likely influenced by $\mathrm{N}$ status of soils, growing season, and environmental conditions. Usually genotype selection is much more important than $\mathrm{N}$ application 


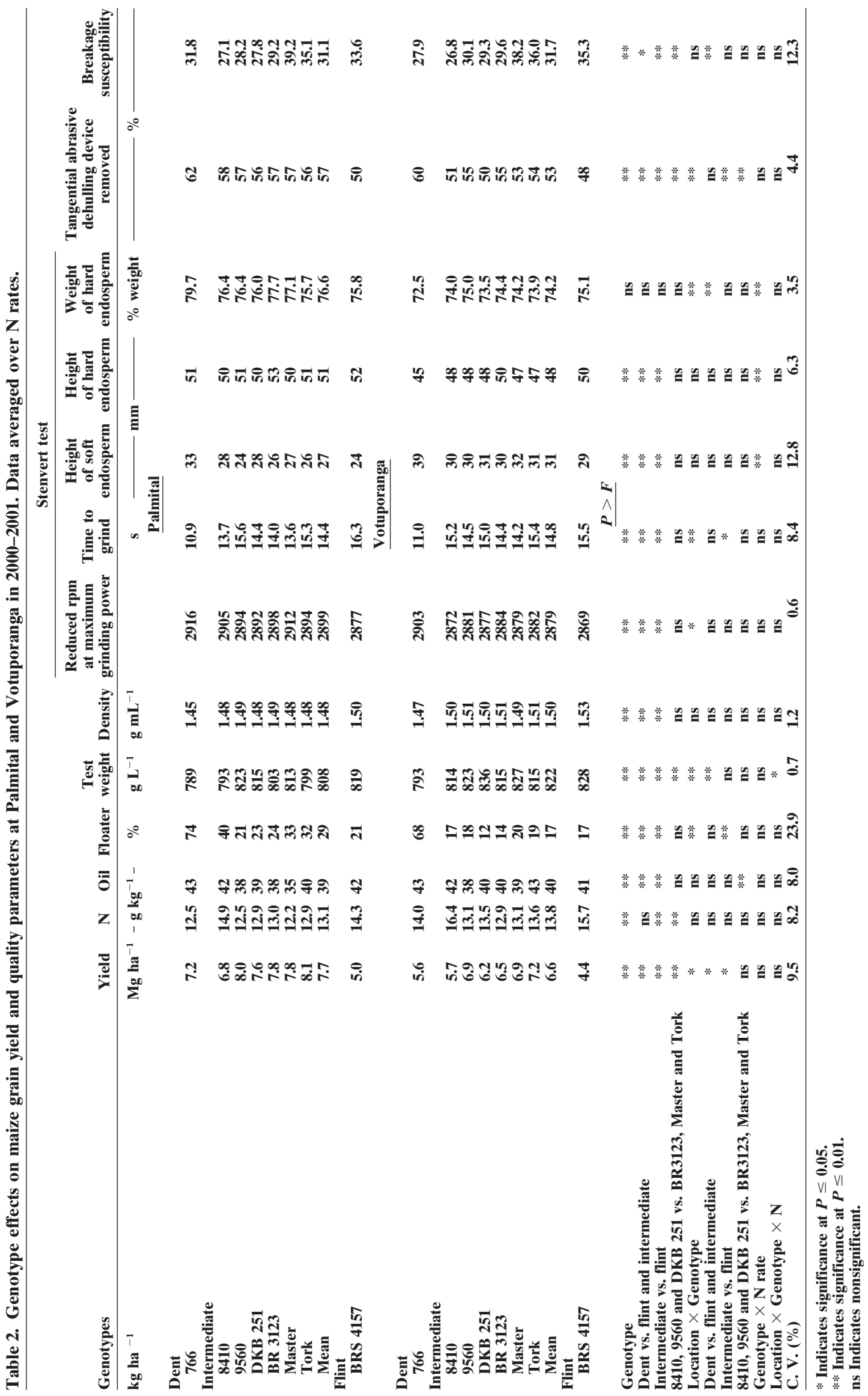


Table 3. Genotype differences on maize yield and grain quality parameters at Palmital in 2001-2002. Data are averaged over $\mathbf{N}$ rates.

\begin{tabular}{|c|c|c|c|c|c|c|c|c|c|c|c|}
\hline \multirow[b]{2}{*}{ Genotypes } & \multirow[b]{2}{*}{ Yield } & \multirow[b]{2}{*}{$\mathbf{N}$} & \multirow[b]{2}{*}{ Floater } & \multirow[b]{2}{*}{$\begin{array}{c}\text { Test } \\
\text { weight }\end{array}$} & \multirow[b]{2}{*}{ Density } & \multicolumn{4}{|c|}{ Stenvert test } & \multirow{2}{*}{$\begin{array}{c}\text { Tangential } \\
\text { abrasive } \\
\text { dehulling } \\
\text { device } \\
\text { removed }\end{array}$} & \multirow{2}{*}{$\begin{array}{c}\text { Breakage } \\
\text { susceptibility }\end{array}$} \\
\hline & & & & & & $\begin{array}{l}\text { Reduced rpm } \\
\text { at maximum } \\
\text { grinding power }\end{array}$ & $\begin{array}{c}\text { Time to } \\
\text { grind }\end{array}$ & $\begin{array}{c}\begin{array}{c}\text { Height } \\
\text { of soft } \\
\text { endosperm }\end{array}\end{array}$ & $\begin{array}{c}\text { Height } \\
\text { of hard } \\
\text { endosperm }\end{array}$ & & \\
\hline & $\mathrm{Mg} \mathbf{h a}^{-}$ & $\mathrm{g} \mathrm{kg}^{-1}$ & $\%$ & $\mathrm{~g} \mathrm{~L}^{-1}$ & $\mathrm{~g} \mathrm{~mL}^{-1}$ & & $\mathbf{s}$ & $=\mathbf{m}$ & $\mathbf{m}$ & 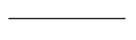 & $\%$ \\
\hline \multicolumn{12}{|c|}{0} \\
\hline Tropical-AG 1051 & 10.1 & 14.9 & 92 & 709 & 1.54 & 2925 & 8.8 & 38 & 54 & 71 & 31.0 \\
\hline Temperate-P 32R21 & 8.7 & 18.0 & 100 & 702 & 1.55 & 2880 & 11.5 & 36 & 49 & 56 & 19.1 \\
\hline Temperate-212 & 6.3 & 15.1 & 73 & 742 & 1.52 & 2896 & 11.1 & 38 & $\mathbf{5 0}$ & 67 & 20.1 \\
\hline Mean & 8.4 & 16.0 & 88 & 718 & 1.54 & 2900 & 10.5 & 37 & 51 & 66 & 23.7 \\
\hline \multicolumn{12}{|l|}{ Flint and intermediate } \\
\hline Intermediate-BR 3123 & 7.9 & 16.2 & 21 & 785 & 1.58 & 2860 & 14.7 & 27 & 55 & 56 & 23.8 \\
\hline Flint-BR 4157 & 3.7 & 18.7 & 28 & 785 & 1.58 & 2850 & 16.1 & 26 & 53 & 49 & 24.1 \\
\hline Mean & 5.8 & 17.5 & 25 & 785 & 1.58 & 2855 & 15.4 & 27 & 54 & 53 & 24.0 \\
\hline & \multicolumn{11}{|c|}{$\underline{P}>\boldsymbol{F}$} \\
\hline Genotype & $* *$ & ** & ** & ** & $*$ & $* *$ & ** & *** & ** & ** & ** \\
\hline Dent vs. flint and intermediate & *** & ** & ** & ** & $*$ & ** & ** & ** & ** & ** & ns \\
\hline Intermediate vs. flint & $* *$ & ** & $*$ & ns & ns & $*$ & *** & $* *$ & ns & ** & ns \\
\hline Tropical vs. temperate (intermediate) & $* *$ & ** & ns & ns & ns & $* *$ & *** & *** & ns & ** & ** \\
\hline P 32R21 vs. DKB 212 (temperate) & $* *$ & $* *$ & ** & ** & ns & ns & ns & ** & ns & ** & ns \\
\hline Genotype $\times \mathbf{N}$ & ns & $*$ & ns & ns & ns & & ns & ns & ns & ns & ns \\
\hline C. V. $(\%)$ & 18.9 & 7.6 & 13.2 & 3.3 & 3.4 & 0.7 & 5.8 & 10.9 & 6.4 & 8.4 & 11.1 \\
\hline
\end{tabular}

* Indicates significance at $P \leq \mathbf{0 . 0 5}$.

** Indicates significance at $\boldsymbol{P} \leq \mathbf{0 . 0 1}$.

ns Indicates nonsignificant.

Table 4. Influence of $\mathbf{N}$ fertilizer rates on maize yield and grain quality parameters at Palmital and Votuporanga in $2000-2001$.

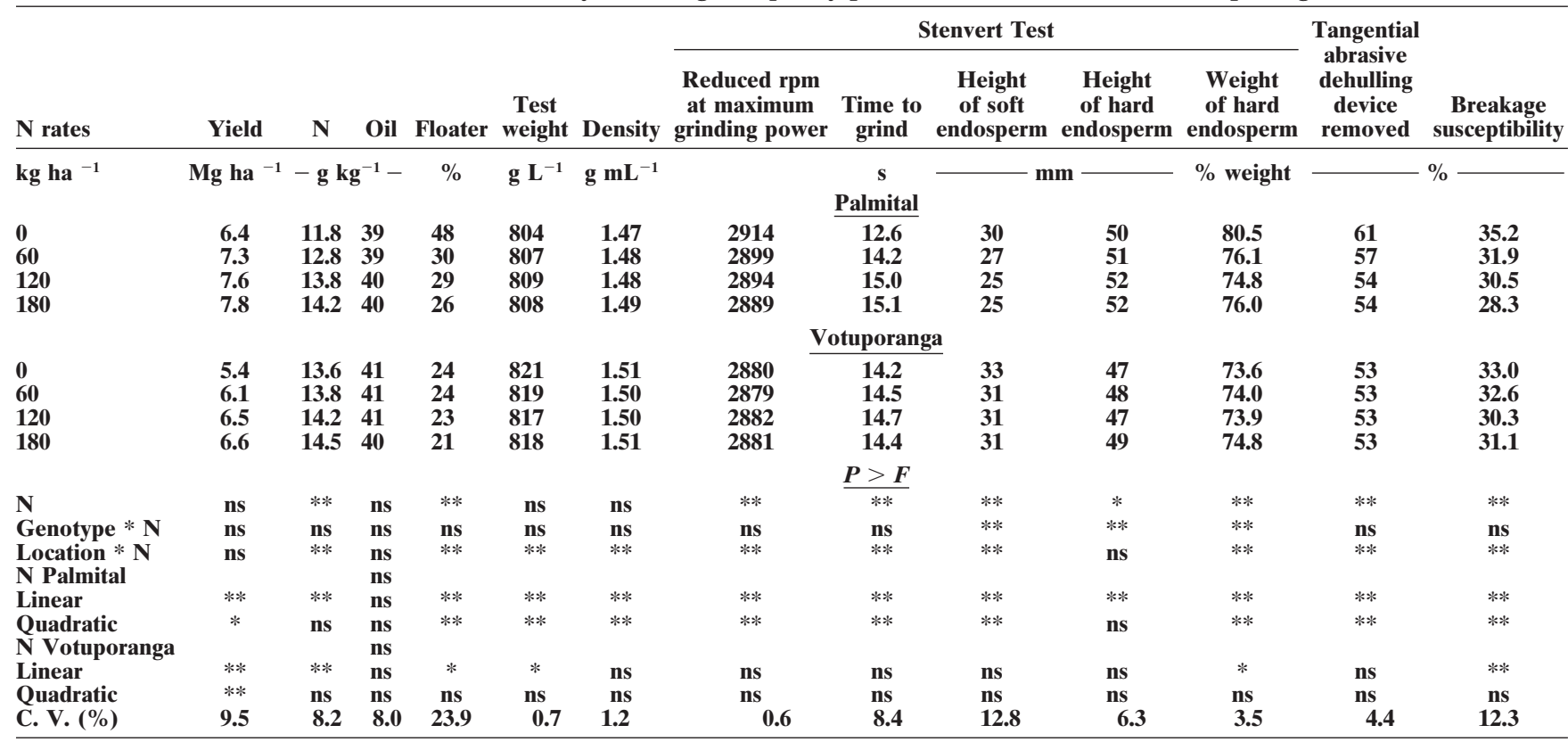

* Indicates significance at $\boldsymbol{P} \leq \mathbf{0 . 0 5}$.

** Indicates significance at $\boldsymbol{P} \leq \mathbf{0 . 0 1}$.

ns Indicates nonsignificant.

Table 5. Influence of $\mathbf{N}$ fertilizer rates on maize yield and grain quality parameters at Palmital in 2001-2002.

\begin{tabular}{|c|c|c|c|c|c|c|c|c|c|c|c|}
\hline \multirow[b]{2}{*}{$\mathrm{N}$ rates } & \multirow[b]{2}{*}{ Yield } & \multirow[b]{2}{*}{$\mathbf{N}$} & \multirow[b]{2}{*}{ Floater } & \multirow[b]{2}{*}{$\begin{array}{c}\text { Test } \\
\text { weight }\end{array}$} & \multirow[b]{2}{*}{ Density } & \multicolumn{4}{|c|}{ Stenvert test } & \multirow{2}{*}{$\begin{array}{c}\text { Tangential } \\
\text { abrasive } \\
\text { dehulling } \\
\text { device } \\
\text { removed }\end{array}$} & \multirow[b]{2}{*}{$\begin{array}{c}\text { Breakage } \\
\text { susceptibility }\end{array}$} \\
\hline & & & & & & $\begin{array}{c}\text { Reduced rpm } \\
\text { at maximum } \\
\text { grinding power }\end{array}$ & $\begin{array}{c}\text { Time to } \\
\text { grind }\end{array}$ & $\begin{array}{c}\begin{array}{c}\text { Height } \\
\text { of soft } \\
\text { endosperm }\end{array} \\
\end{array}$ & $\begin{array}{c}\text { Height } \\
\text { of hard } \\
\text { endosperm }\end{array}$ & & \\
\hline $\mathrm{kg} \mathrm{ha}^{-1}$ & $\mathrm{Mg} \mathrm{ha}^{-1}$ & $\mathrm{~g} \mathrm{~kg}^{-1}$ & $\%$ & $\mathrm{~g} \mathrm{~L}^{-1}$ & $\mathrm{~g} \mathrm{~mL}^{-1}$ & & $\mathbf{s}$ & $\mathbf{m m}$ & $\mathbf{m m}$ & $\%$ & \\
\hline 0 & 6.9 & 15.8 & 63 & 752 & 1.56 & 2883 & 12.2 & 86 & 59.8 & 64 & 25.5 \\
\hline 60 & 7.3 & 16.5 & 63 & 740 & 1.53 & 2889 & 12.0 & 86 & 61.8 & 60 & 23.7 \\
\hline 120 & 7.5 & 17.1 & 61 & 742 & 1.56 & 2884 & 12.6 & 84 & 62.5 & 57 & 24.2 \\
\hline \multirow{2}{*}{180} & 7.6 & 16.9 & 63 & 746 & 1.56 & 2871 & 13.0 & 85 & 62.7 & 58 & 21.9 \\
\hline & \multicolumn{11}{|c|}{$\boldsymbol{P}>\boldsymbol{F}$} \\
\hline $\mathbf{N}$ rates & ns & $*$ & ns & ns & ns & ns & $*$ & $*$ & ns & $* *$ & $* *$ \\
\hline N Linear & ns & $* *$ & ns & ns & ns & ** & ** & $* *$ & ns & $* *$ & *** \\
\hline N Quadratic & ns & ns & ns & ns & ns & $*$ & ns & ns & ns & ns & ns \\
\hline Genotype * N & ns & $*$ & ns & ns & ns & & ns & ns & ns & ns & ns \\
\hline C. V. $(\%)$ & 18.9 & 7.6 & 13.2 & 3.3 & 3.4 & 0.7 & 5.8 & 10.9 & 6.4 & 8.4 & 11.1 \\
\hline
\end{tabular}

* Indicates significance at $\boldsymbol{P} \leq \mathbf{0 . 0 5}$.

** Indicates significance at $\boldsymbol{P} \leq \mathbf{0 . 0 1}$.

ns Indicates nonsignificant. 


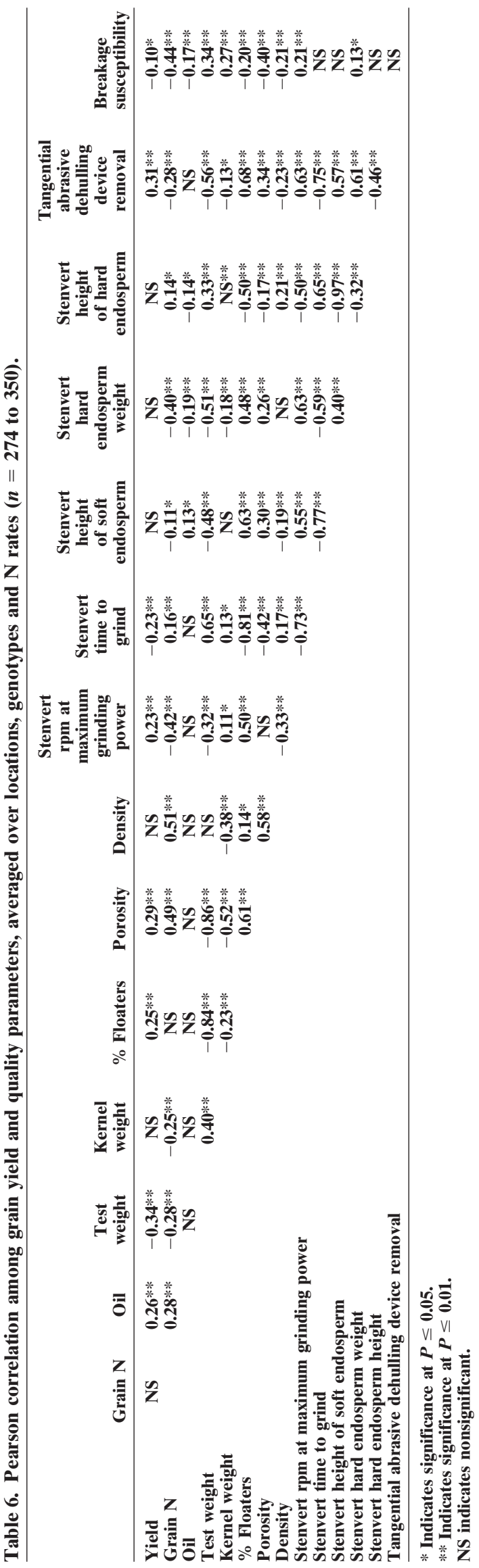

rate and other production practices to produce high quality maize grain (Mason and D'Croz-Mason, 2002).

\section{Grain Yield and Quality Relationships}

Since different hardness tests measure similar characteristics, correlations among tests would be expected to be greater than 0.5 and were usually present (Table 6). The only other correlation greater than 0.5 was between grain $\mathrm{N}$ concentration and specific density (0.51). Because of the large number of degrees of freedom, many correlations between 0.10 and 0.50 were declared significant but less important. Correlations with grain yield for all quality parameters were $\leq 0.30$, suggesting that both high grain yield and excellent grain quality for different uses can be produced simultaneously. Very few significant correlations between grain oil concentration and quality parameters were present, as expected since most kernel hardness and breakage susceptibility are associated with endosperm properties, while oil is largely found in the germ (Mason and D'Croz-Mason, 2002). Grain $\mathrm{N}$ concentration tended to be associated with increased hardness and decreased breakage susceptibility, but this relationship was not strong, as previously reported (Kniep and Mason, 1989). The highest correlation with breakage susceptibility was with grain $\mathrm{N}$ concentration (0.44), and in general, showed little correlation with the kernel hardness parameters, as previously reported (Shandera et al., 1997).

On the basis of the selection criteria of Fox et al. (1992) for desirable grain quality characteristics for wet milling, none of the genotypes in these experiments had both low grain $\mathrm{N}$ and high test weights (Tables 2 and 3 ); however, zero $\mathrm{N}$ application did result in lower grain $\mathrm{N}$ concentrations without affecting the test weight greatly (Tables 4 and 5). In contrast, the flint genotypes with high $\mathrm{N}$ application rates produced grain with low TADD removal, high Stenvert hardness, and low percentage of floaters (Tables 2 through 5), which are associated with desirable dry milling quality (Shandera et al., 1997; Wehling et al., 1996), but they had lower grain yields at least partially because of one of the flint genotypes not being a hybrid. There was great variation among the intermediate kernel-type genotypes for grain yield, hardness, and breakage susceptibility (Table 2 and 3), suggesting that selecting the appropriate intermediate kernel-type genotypes in combination with high $\mathrm{N}$ rates (Tables 5 and 6) would result in high grain yield and quality, which likely would be economically important. Further grain quality characterization of intermediate kernel-type maize genotypes in Brazil is merited.

\section{CONCLUSIONS}

This study extends the knowledge about maize genotype and $\mathrm{N}$ application rate effects on grain quality to the wide diversity of maize genotypes and production environments present in tropical Brazil. Nitrogen application increased kernel hardness and decreased breakage susceptibility to a minor extent, while genotype had a much larger influence on grain quality parameters. The limited correlation of grain yield, oil concentration, and breakage susceptibility with hardness parameters 
suggests that high yield maize production with corresponding high dry milling quality grain is feasible. Further, the large variation in grain yield and dry milling grain quality in intermediate-kernel type genotypes used in Brazil presents short-term potential to select genotypes that produce both high yield and good dry milling grain quality.

\section{REFERENCES}

Arnold, J.M., L.F. Bauman, and H.S. Aycock. 1977. Interrelationships among protein, lysine, oil, certain mineral element concentrations, and physical kernel properties of two maize populations. Crop Sci. 17:421-425.

Association of Official Analytical Chemists (AOAC). 1990a. Method 990.03. In K. Helrich (ed.) Official methods of plant analysts (15th ed.). AOAC, Arlington, VA.

Association of Official Analytical Chemists (AOAC). 1990b. Method 920.39. In K. Helrich (ed.) Official methods of plant analysts (15th ed.) AOAC, Arlington, VA.

Bauer, P.J., and P.R. Carter. 1986. Effect of seeding date, plant density, moisture availability and soil nitrogen fertility on maize kernel breakage susceptibility. Crop Sci. 26:1220-1226.

Corrêa, S., C. Santos, B.B. Kist, E. Reetz and R.R. Beling. 2004. Anuário Brasileiro do milho. Editora Gazeta Santa Cruz, Santa Cruz do Sul, Brazil.

Dorsey-Redding, C., C.R. Hurburgh, Jr., L.A. Johnson, and S.R. Fox. 1991. Relationships among maize quality factors. Cereal Chem. 68:602-605.

Duarte, A.P., J.C. Kiehl, M.A.F. Camargo, and P.C. Reco. 2003. Accumulation of dry matter and nutrients in tropical cultivars and temperate maize cultivars in Brazil. Rev. Brasil. Milho Sorgo 2(3):1-19.

Food and Agricultural Organization (FAO). 2003. FAOSTAT data base results [Online]. Available at http://apps.fao.org/page/collections? subset $=$ agriculture (Verified 23 May 2005). FAO, Rome.

Fox, S.R., L.A. Johnson, C.R. Hurburgh, Jr., C.R. Dorsey-Redding, and T.B. Bailey. 1992. Relations of grain proximate composition and physical properties to wet-milling characteristics of maize. Cereal Chem. 69:191-197.

Instituto Brasileiro de Gerografia e Estatitica (IBGE). 2003. Levantamento sistemático de produção agrícola. Instituto Brasileiro de Gerografia e Estatítica. Rio de Janeiro, Brazil.

Johnson, D.Q., and W.A. Russell. 1982. Genetic variability and relationships of physical grain quality traits in the BSSS population of maize. Crop Sci. 22:805-809.

Kniep, K.R., and S.C. Mason. 1989. Kernel breakage susceptibility and density of normal and opaque-2 maize grain as influenced by irrigation and nitrogen. Crop Sci. 29:158-163.

Littel, R.C., G.A. Milliken, W.W. Stroup, and R.D. Wolfinger. 1996. SAS system for mixed models. SAS Institute, Cary, NC.
Manoharkumar, B.P., P. Gerstenkorn, H. Zwingelberg, and H. Bolling. 1978. On some correlations between grain composition and physical characteristics to the dry milling performance of shelled corn. J. Food Sci. Tech. 15:1-6.

Mason, S.C., and N.E. D'Croz-Mason. 2002. Agronomic practices influence maize grain quality. J. Crop Prod. 5:75-91.

Oikeh, S.O., J.G. Kling, and A.E. Okoruwa. 1998. Nitrogen management effects on maize grain quality in the West African moist savanna. Crop Sci. 38:1056-1061.

Paulsen, M.R., and L.D. Hill. 1985. Maize quality factors affecting dry milling performance. J. Agric. Eng. Res. 31:255-263.

Paulsen, M.R., L.D. Hill, D.G. White, and G.F. Sprague. 1983. Breakage susceptibility of corn-belt genotypes. Trans. ASAE 32:10071014.

Peplinski, A.J., M.R. Paulsen, R.A. Anderson and W.F. Kwolek. 1989. Physical, chemical, and dry milling characteristics of corn of corn hybrids from various genotypes. Cereal Chem. 66:117-120

Pomeranz, Y., Z. Czuchajowska, C.R. Martin, and F.S. Lei. 1985. Determination of maize hardness by the Stenvert hardness tester. Cereal Chem. 61:108.

Reichert, R.D., R.T. Tyler, A.E. York, D.J. Schwab, J.E. Tatarynovich, and M.A. Mwasaru. 1986. Description of a production model of the tangential abrasive dehulling device and its application to breeder's samples. Cereal Chem. 63:201-207.

Shandera, D.L., D.S. Jackson, and B.E. Johnson. 1997. Quality factors impacting processing of maize dent hybrids. Maydica 42:281-289.

Singh, S.S., and M.F. Finner. 1983. A centrifugal impacter for damage susceptibility evaluation of shelled corn. Trans. ASAE 26:18581864.

Thompson, R.A., and G.W. Isaacs. 1967. Porosity determinations of grains and seeds with an air-comparison pycnometer. Trans. ASAE 10(5):693-696.

Tsai, C.Y., D.M. Huber, D.V. Glover, and H.L. Warren. 1984. Relationship of $\mathrm{N}$ deposition to grain yield $\mathrm{N}$ responses of three maize hybrids. Crop Sci. 24:277-281.

Tsai, C.Y., I. Dweikat, D.M. Huber, and H.L. Warren. 1992. Interrelationship of nitrogen nutrition with maize (Zea mays) grain yield, nitrogen use efficiency and grain quality. J. Sci. Food Agric. 58:1-8.

Vyn, T.J., and M. Tollenaar. 1998. Changes in chemical and physical quality parameters of maize grain during three decades of yield improvement. Field Crops Res. 59:135-140.

Watson, S.A., and F.L. Hercum. 1986. Comparison of eight devices for measuring breakage susceptibility of shelled corn. Cereal Chem. 63 139-142.

Wehling, R.L., D.S. Jackson, and B.R. Hamaker. 1996. Prediction of corn dry-milling quality by near-infrared spectroscopy. Cereal Chem. 73:543-546.

Wu, Y.V., and R.R. Bergquist. 1991. Relation of corn density to yields of dry milling products. Cereal Chem. 68:542-544.

Yuan, J., and R.A. Flores. 1996. Laboratory dry-milling performance of white corn: Effect of physical and chemical corn characteristics. Cereal Chem. 73:574-578. 